Review

\title{
Rhizoremediation: A Beneficial Plant-Microbe Interaction
}

\author{
Irene Kuiper, Ellen L. Lagendijk, Guido V. Bloemberg, and Ben J. J. Lugtenberg \\ Leiden University, Institute of Biology Leiden, Wassenaarseweg 64, 2333 AL Leiden, The Netherlands
}

Submitted 3 March 2003. Accepted 10 September 2003.

\begin{abstract}
Worldwide, contamination of soil and ground water is a severe problem. The negative effects of pollutants on the environment and on human health are diverse and depend on the nature of the pollution. The search for alternative methods for excavation and incineration to clean polluted sites resulted in the application of bioremediation techniques. In this review, we describe some generally accepted bioremediation tools and subsequently focus on the combination of two approaches, phytoremediation and bioaugmentation, resulting in rhizoremediation. During rhizoremediation, exudates derived from the plant can help to stimulate the survival and action of bacteria, which subsequently results in a more efficient degradation of pollutants. The root system of plants can help to spread bacteria through soil and help to penetrate otherwise impermeable soil layers. The inoculation of pollutant-degrading bacteria on plant seed can be an important additive to improve the efficiency of phytoremediation or bioaugmentation.
\end{abstract}

Additional keywords: consortium, Pseudomonas, root exudate.

Bioremediation: A natural method

for the restoration of polluted sites.

The estimated costs for the clean up of contaminated sites with conventional techniques such as incineration and landfilling are enormous. In the next decades, billions of dollars will be spent to clean up all sites polluted with polycyclic aromatic hydrocarbons (PAHs) (Rosenberg 1993). In the United States alone, restoration of all contaminated sites will cost approximately $\$ 1.7$ trillion. In addition, the conventional techniques are not always sufficient (Dixon 1996). Incineration can result in air pollution, leaches from landfills in the form of water and gases can reach the ground water and drinking water wells, whereas excavation of soil can lead to the generation of toxic air emissions. Therefore, the search for alternative methods to restore polluted sites in a less expensive, less labor-intensive, safe, and environmentally friendly way is required. Such an alternative method is bioremediation, which is defined as the action of microbes or other biological systems to degrade environmental pollutants (Caplan 1993; Dua et al. 2002). Bioremediation can be applied in situ without the removal and transport of polluted soil and without the disturbance of the soil matrix. Another advantage is that bacterial degradation usually results in complete mineralization of the pollutant (Heitzer and Sayler 1993).

In the past two decades, the application of bioremediation has been growing, partly because of the better understanding of

Corresponding author: B. J. J. Lugtenberg; Telephone: (+)31-71-5275065; Fax: (+)31-71-5275088; E-mail: lugtenberg@ rulbim.leidenuniv.nl microbial processes in soil. Especially sites polluted with PAHs are treated with some success, with the Exon Valdez oil spill as an important example (Pritchard et al. 1992). In order to design the most effective method of soil and water treatment, and to best decide which technique will be applied, an elaborate study of the site should be made. Important parameters for bioremediation are i) the nature of the pollutants, ii) the soil structure and hydrogeology (movement of pollutants through soil and ground water), and iii) the nutritional state and microbial composition of the site (Blackburn and Hafker 1993; Dua et al. 2002; Long 1993). In many cases, the most effective solution combines several treatment techniques. These treatments can last for a long time (years or decades), are still in progress on many sites, and often are applied in combination with other techniques; therefore, it is difficult to estimate the efficacy of bioremediation. However, to become a generally accepted technique, the effectiveness and predictability should be demonstrated. To this end, a reliable monitor and evaluation strategy is required (Heitzer and Sayler 1993; Widada et al. 2002).

Natural attenuation. When a site gets polluted, the composition of the indigenous microbial population in the soil and ground water will adapt to this new situation. Bacteria able to use the pollutant substrates as a nutrient source will be able to proliferate and may become dominant (Liu and Suflita 1993). The natural, nonengineered process of degradation of xenobiotics by the indigenous microbial population is referred to as natural attenuation, and is regarded as the simplest form of bioremediation. The Environmental Protection Agency (EPA, United States) defines natural attenuation, or intrinsic remediation, as a combination of degradation, dispersion, dilution, sorption, volatilization, and chemical and biochemical stabilization of contaminants. Although, in the past, this "treatment" method often was referred to as a do-nothing approach, it increasingly has been recognized as a tool to treat contaminated sites. Natural attenuation was already successful for benzene, toluene, ethylene, and xylene (BTEX) compounds present in ground water (Barton 2000; Grossl 2000; Spadaro 2000). It is applied mainly on sites with "low" environmental or public value, when time is not a limiting factor, because restoration can take a long time (decades), or at sites where no other restoration techniques are applicable. Natural attenuation cannot be applied at sites close to domestic areas or at sites with high environmental value, such as nature resorts. Time also can be a limiting factor because adaptation of the indigenous microbes can take a long time, depending on the nature of the introduced xenobiotic (Leahy and Colwell 1990). By-products formed during incomplete degradation of other pollutants can be hazardous. For example, toxic 1-napthol can be formed by aerobic transformation of naphthalene, whereas the very carcinogenic compound vinyl chloride can be formed after anaerobic con- 
version of tri-chloroethylene (Heitzer and Sayler 1993). Heavy metals are not destroyed using natural attenuation; however, they can be immobilized or volatilized. In addition, microbes with the suitable catabolic genes are not available on the site for all xenobiotics, which is proven by the accumulation of toxic and recalcitrant compounds in the environment (Pieper and Reineke 2000).

Sampling wells can be placed at the site to control a plume with pollutants and monitor its track of movement through soil or in ground water. Analytical equipment can be used to monitor chemical parameters such as the concentration of xenobiotics, intermediate formation, end product formation, electron acceptor consumption, and toxicity. Methods to monitor biological parameters such as the composition, size, and degrading activity of the microbial population are enumerated using plate counts, total DNA extraction, direct mRNA isolation, metabolic biomarkers, and the use of reporter bacteria (Heitzer and Sayler 1993). Subsequently, estimations can be made about the degradation rate in combination with the spreading of the plume. This process is named monitored natural attenuation. At this moment, natural attenuation as a tool has been reviewed and discussed in order to develop criteria and methods to follow the process of intrinsic bioremediation and to make this process more predictable and, therefore, more suitable as a bioremediation tool (Smets et al. 2002).

Bioaugmentation. Bioaugmentation is a method to improve degradation and enhance the transformation rate of xenobiotics by the injection (seeding) of specific microbes, able to degrade the xenobiotics of interest. Many microbes are described to have the genetic tools to mineralize recalcitrant pollutants such as PAHs, chlorinated aliphatics and aromatics, nitroaromatics, and long-chain alkanes (Cerniglia 1993; Cerniglia and Heitkamp 1987; Grosser et al. 1991; Heidelberg et al. 2002; Kastner and Mahro 1996). These microbes can be wild-type isolates, but also can be genetically modified strains equipped with catabolic plasmids, containing the relevant degradation genes (Dixon 1996; King et al. 1990; Yee et al. 1998). Analysis of the efficiency of microbial degradation showed that chlorinated derivatives, especially, are difficult to metabolize and frequently are degraded by means of co-metabolism (Dean-Ross 1987; Heitkamp and Cerniglia 1989). Co-metabolism is defined as the oxidation of nongrowth substrates during the growth of an organism on another carbon or energy source.

Construction of genetically modified strains is especially relevant in the case of pollutants, such as polychlorinated biphenyls (PCBs) and chloroethylenes, for which, as far as is known, no microbial catabolic pathways have been evolved (Megharaj et al. 1997) or no optimal pathways are available (Brazil et al. 1995). Genetically engineered microbes (GEMs) have been constructed in order to degrade those pollutants. These GEMs can be equipped with new metabolic routes which, for example, are constructed by combining parts of known pathways or by optimizing the known pathways; for example, by overexpression of certain genes or operons (Chakrabarty 1996; Pieper and Reineke 2000; Timmis and Pieper 1999). However, until now the generation of GEMs has not developed into a widely used approach. Both the inability to improve the action of microbial consortia and the restriction of degrading only a few pollutants limit the use of GEMs. In addition, legislative problems arise when GEMs are introduced in the environment (Hamer 1993; Sayler and Ripp 2000). One example of a field release is the genetically engineered Pseudomonas fluorescens HK44 (King et al. 1990), which degrades naphthalene and was used to monitor the presence of naphthalene on a PAH-polluted site (Ford et al. 1999).

The lab scale results of seeding (wild type) microbes for degradation of soil and water pollutants are ambiguous. Goldstein and associates (1985) reported five possible reasons for the failure of bacterial inocula. First, the concentration of the contaminants at a site can be too low to support growth of the inoculum. This also includes the problem of low bioavailability of certain pollutants. Second, the presence of certain compounds in the environment can inhibit the growth or activity of the inoculum. Third, protozoan-grazing rates on the inoculum can be higher than the growth rates of the bacteria, resulting in a decline of the bacterial population. Fourth, the inoculum can prefer to use other carbon sources present in soil, instead of the contaminant. Fifth, inocula may fail because of the inability of the microbes to spread through the soil and reach the pollutant.

The influence of the inoculum size was studied by Ramadan and associates (1990) during the remediation of water. It was suggested that increasing the concentration of the inoculated population still resulted in an initial decline of the population, but that the remaining concentration of the population was sufficiently high to survive. Kastner and associates (1998) described the negative effects of the salinity of the minimal medium used for the introduction of the bioinoculant on both the seeded and indigenous microbial populations. These studies reflect the importance of various parameters, such as oxygen, $\mathrm{pH}$, temperature, water activity, electron acceptors, pressure, bioavailability of the pollutants, and the presence of nutrients, for the success of bioremediation (Leahy and Colwell 1990). Fertilization of sites using compost, nitrogen, phosphorus, and carbon has been reported to enhance degradation of pollutants by both the indigenous microbial communities and the introduced microbes (Brodkorb and Legge 1992; Mahro et al. 1994; Namkoong et al. 2002; Ramadan et al. 1990; Wang et al. 1990). Microorganisms contain approximately $14 \%$ nitrogen, $3 \%$ phosphorus, and $1 \%$ sulfur. Especially during growth on PAHs, which contain hydrogen, carbon, and sometimes small amounts of nitrogen and sulfur, microbes require additional phosphorus, sulfur, and nitrogen (Rosenberg 1993). However, the addition of nutrients yielded inconclusive results, because publications exist in which no influence of the addition of limiting nutrients was shown (Heitkamp and Cerniglia 1989; Manilal and Alexander 1991). This unpredictability of bioremediation often is caused by the lack of knowledge of the persistence of microbial populations in the environment (Head 1998). In addition, these nutrient additives, $\mathrm{pH}$ regulation, and mechanical tilling to aerate soil and spread inoculated microbes through soil make the use of the bioremediation technique economically less feasible and also alter the ecosystem (Goldstein et al. 1985; Heitkamp and Cerniglia 1989). For that reason, the focus of bioremediation studies has shifted from the construction of bacteria, able to degrade pollutants, to the determination of factors which are limiting the degradation rates (Head 1998).

PAH degradation by microbes. As mentioned previously, PAHs (Fig. 1) represent a large group of soil pollutants. Many higher-ringed PAHs are resistant toward degradation and described to be toxic, mutagenic, or carcinogenic; therefore, they are an important risk to the environment and human health. The main input sources of PAH pollutions, described by Morgan and Watkinson (1989), are leaches from old storage tanks, road surfaces, and domestic waste; oil spills; tanker leakage; incomplete fossil fuel combustion; and seepage from natural oil reservoirs. Once these pollutants enter the soil, they are trapped into soil pores and immobilized by adsorption to the soil matrix (Aprill and Sims 1990; Reddy and Sethunathan 1983). Biological degradation then remains as the most significant means of decomposition. The ability of microbes to degrade oil components was already recognized at the start of the twentieth century. Stormer (1908) and Sohngen (1913) (Cerniglia and Heitkamp 1987) isolated bacteria from oil which were able to 
degrade PAHs. The first presentation of the metabolic pathway and the enzymatic reactions resulting in the mineralization of naphthalene was by Davies and Evans (1964). Since then, the degradation of PAHs by microbes has been studied intensively, and this ability was identified to be present in a wide variety of bacteria, fungi, and algae (Cerniglia 1997; Dagher et al. 1997; Johnson and Jacobsen 1996; Leahy and Colwell 1990; Sanseverino et al. 1993; Shuttleworth and Cerniglia 1996). The general pathway for the bacterial degradation of naphthalene is depicted in Figure 2. The bacterial PAH catabolic genes often are located on large plasmids, together with regulatory genes and, in some cases, with genes responsible for chemotaxis toward the PAH (Grimm and Harwood 1997). The presence of these catabolic plasmids is probably the cause of the adaptation of the indigenous microbes toward PAH pollutants, because they are reported to be self-transmissible and horizontal transfer of naphthalene catabolic genes has been described (StuartKeil et al. 1998). Based on their similarity, it was even suggested for the class of naphthalene catabolic plasmids that they all are related (Yen and Serdar 1988).

Studies of the degradation of PAHs with more than three fused rings are less ubiquitous, but the number of organisms found to degrade these aromatics is increasing (Cerniglia 1993; Grosser et al. 1991; Heitkamp and Cerniglia 1989; Kanaly and Harayama 2000). For PAHs with more than three fused rings, co-metabolism often serves as the main route for degradation. Two- or three-ringed PAHs are especially able to function as a carbon source during the co-metabolic degradation of higherringed PAHs (Schwab et al. 1995).

Many PAHs are very hydrophobic, depending upon the number of fused rings; therefore, their water solubility is very low. Uptake of PAHs by bacteria proceeds via the water phase and, therefore, depends upon its solubility in water (Bouwer and Zehnder 1993). In addition, the sorption to soil particles will protect these molecules from degradation by microbes and is the main reason for their long-term persistence in soil. The bioavailability of xenobiotics can be improved by the use of surfactants. Surfactants are amphipathic molecules with both a hydrophobic and a hydrophilic part. Many microbes can pro-

\begin{tabular}{|c|c|c|}
\hline Structural formula & $\begin{array}{c}\text { Molecular } \\
\text { weight }\end{array}$ & $\begin{array}{l}\text { Water solubility } \\
\text { at } 25^{\circ} \mathrm{C}(\mathrm{mg} / \mathrm{L})\end{array}$ \\
\hline naphthalene & 128.19 & 31.7 \\
\hline phenanthrene & 178.22 & 1.3 \\
\hline fluoranthene & 202.60 & 0.3 \\
\hline pyrene & 202.30 & 0.14 \\
\hline chrysene & 228.28 & 0.002 \\
\hline benzo[a]pyrene & 252.0 & 0.003 \\
\hline
\end{tabular}

Fig. 1. Structures, molecular weights, and water solubility of some polycyclic aromatic hydrocarbons. duce such surface-active agents, referred to as biosurfactants. These accumulate at interfaces, are able to lower the surface tension between interfaces, and can form micelles (Desai and Banat 1997; Neu 1996; Rosenberg 1993). Intensively studied organisms and their biosurfactants include Pseudomonas aeruginosa strains that produce rhamnolipids (Lang and Wullbrandt 1999; Noordman and Janssen 2002; Providenti et al. 1995; Shreve et al. 1995; Sim et al. 1997) and Bacillus spp. strains that produce surfactins (Fuma et al. 1993; Yakimov et al. 1995). Although the effects of biosurfactants can be dualistic (Allen et al. 1999; Pieper and Reineke 2000) and their mode of action needs further detailed research, the use of biosurfactants can be considered a valuable tool to improve bioremediation.

\section{Phytoremediation.}

Phytoremediation is defined as the use of plants to extract, sequester, or detoxify pollutants. This remediation method is environmental friendly and visually attractive, and the structure of the soil is highly maintained (Khan et al. 2000). Pollutants which can be a target for phytoremediation can be divided into two groups, the elemental pollutants and the organic pollutants (Meagher 2000).

Elemental pollutants. The group referred to as elemental pollutants contains contaminants such as toxic heavy metals and radionuclides. Compared with the organic pollutants, only a few remediation techniques are available for this kind of pollutant, and the use of plants to strip heavy metals from soil is an emerging tool (Clemens et al. 2002; Cobbett and Goldsbrough 2002; Khan et al. 2000). In these cases, the major principles of phytoremediation are i) extraction of the pollutant from soil and translocation to aboveground tissues, ii) sequestering of the pollutant in the root system to prevent further spreading and leaching into soil or ground water, or iii) conversion into less toxic chemicals. For this kind of phytoremediation, various plant species, such as tobacco, sunflower, mustard, maize, and sand rocket, are used, based on the ability to adsorb or hyperaccumulate the pollutant (Meagher 2000). The natural ability to hyperaccumulate metals was found in plants grown on soils which were naturally enriched with heavy metals, and this accumulation was thought to be a defense mechanism against herbivores (Gleba et al. 1999). However, the distribution of such plants is limited and the hyperaccumulating ability is contaminant specific. Genetic alterations of plants can improve the success of phytoremediation. For example, phytoextraction can be improved by an increase in the transpiration rate of plants. An Indian mustard cell line with a transpiration rate of $130 \%$ compared with the wild type plant was able to extract $104 \%$ more lead from soil, whereas increased resistance of plants toward pollutants also can improve their action during phytoremediation (Gleba et al. 1999). The introduction and expression of bacterial genes in plants resulting in enzymes involved in the conversion of xenobiotics is, when the legislative problems for using such plants are disregarded, also a promising tool. Bizily and associates (2000) described the use of Arabidopsis thaliana plants transformed with bacterial genes in order to transform and detoxify organic mercury, and Iimura and associates (2002) described the expression of a manganese-peroxidase gene in transgenic tobacco.

Organic pollutants. The second group of pollutants which can be targeted for phytoremediation is that of the organic pollutants, such as polychlorinated biphenyls, polycyclic aromatic compounds, nitroaromatics, or linear halogenated hydrocarbons. This group of pollutants can be mineralized completely using poplar trees, willow, alfalfa, and different grass varieties. Although the knowledge of the degradation of pollutants by plant metabolic systems is still limited compared with what is known for bacteria, various reports confirm the 
importance of phytoremediation as a newly emerging tool. Degradation of compounds such as tri-chloroethylene (TCE) (Gordon et al. 1998); the explosives 2,4,6-trinitrotoluene (TNT), hexahydro-1,3,5-trinitro-1,3,5-triazine (RDX), glycerol trinitrate (GTN), and nitroglycerin (Best et al. 1997); and PCBs (Kas et al. 1997) using plant enzymes shows the possibilities of phytoremediation. In addition, construction of transgenic plants, as described above, can increase the range of pollutants which can be degraded. For example, Doty and associates (2000) described the construction of a tobacco plant, harboring the mammalian cytochrome P450 2e1, which is able to oxidize a wide range of pollutants such as TCE, ethyl bromide, carbon tetrachloride, chloroform, and vinyl chloride. Shimizu and associates (2002) reported the successful expression of the catechol-degrading gene $c b n A$, which encodes an enzyme involved in the cleavage of the aromatic ring of chlorocatechol in plants.
In order to apply phytoremediation efficiently, the limitations of this technique also should be taken into account. These limitations are i) the time necessary for acceptable effects, ii) the limited depth of the root system, iii) the slow growth of plants, iv) the sensitivity toward some pollutants, v) the problem of being part of a food chain, and vi) the dependence on changes in the climate and winter dormancy (Khan et al. 2000). In addition to the use of transgenic plants, the use of plants which are environmentally well adapted, rapid growing, and deeply rooting can help to overcome these problems and lead to a more effective use of phytoremediation.

\section{Rhizoremediation.}

Plant enzymes establish the degradation of pollutants during phytoremediation; whereas, during natural attenuation or bioaugmentation, the (indigenous) microbial population performs the degradation. In many of these studies, an important contri-

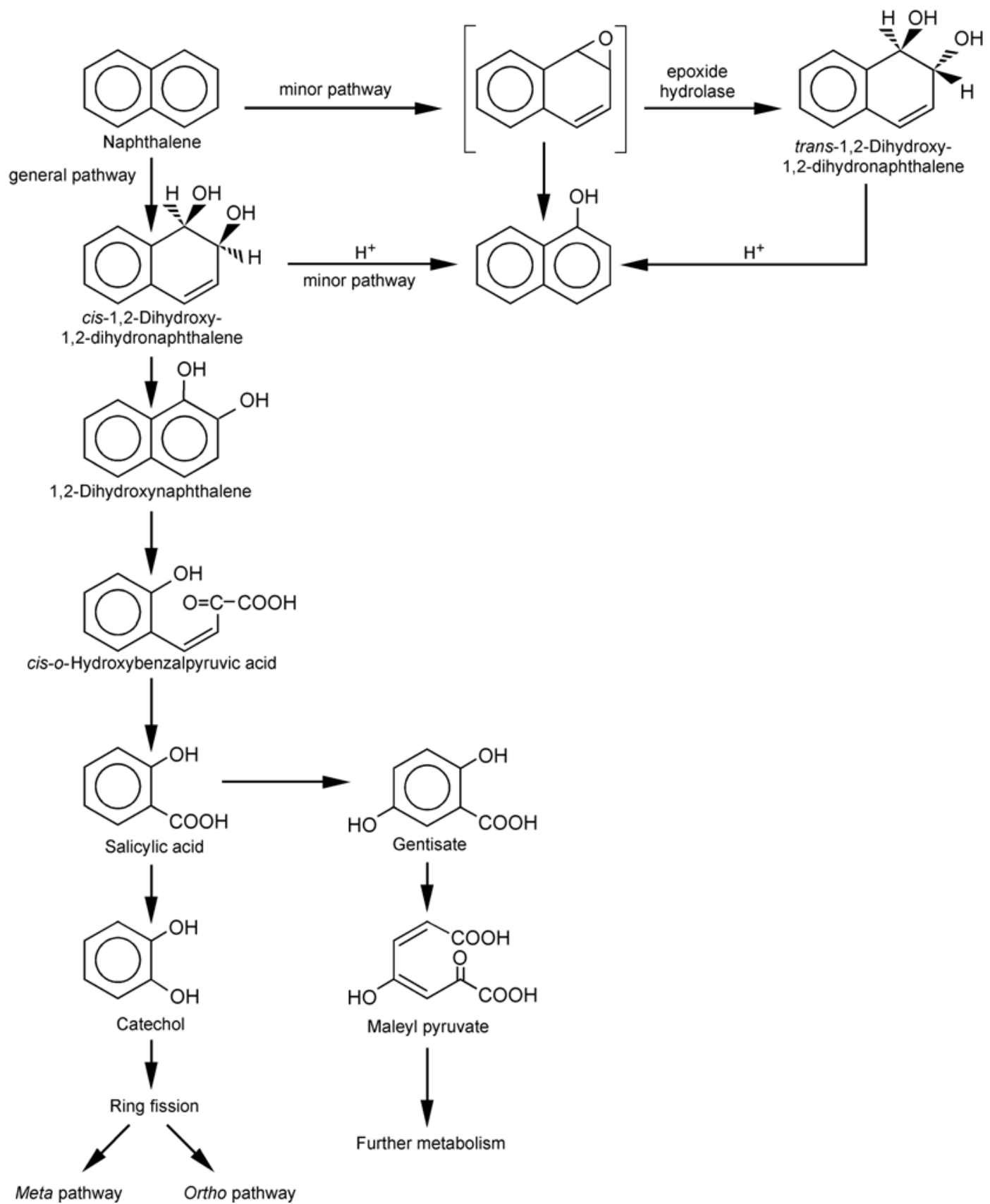

Fig. 2. Bacterial degradation pathway of naphthalene, adapted from van Agteren and associates (1998). 
bution to the degradation of pollutants is ascribed to microbes present in the rhizosphere of plants used during phytoremediation or of plants which are emerging as natural vegetation on a contaminated site. This contribution of the rhizomicrobial population is referred to as rhizoremediation (Anderson et al. 1993; Schwab and Banks 1994). In some cases, rhizosphere microbes are even the main contributors to the degradation process. A plant can be considered to be a solar-driven biological pump and treatment system, attracting water with its root system, accumulating water-soluble pollutants in the rhizosphere, and concluding with the degradation or translocation of the pollutant (Erickson 1997). Although the importance of the rhizosphere community for degradation of pollutants has been recognized, very little is known about the exact composition of the degrading population.

The first studies toward degradation of compounds in the rhizosphere mainly focused on the degradation of herbicides and pesticides (Hoagland et al. 1994; Jacobsen 1997; Zablotowicz et al. 1994). These studies suggested that plants are protected against these compounds by the degrading bacteria. Today, many reports deal with degradation of hazardous organic compounds such as TCE (Walton and Anderson 1990), PAHs (Radwan et al. 1995), and PCBs (Brazil et al. 1995). A number of studies on the degradation of pollutants in the rhizosphere are listed in Table 1. In many of these reports, the composition of the microbial population has not been analyzed in detail. In addition, in many reports, no information about the survival, proliferation, and activity of these populations in the rhizosphere was provided.

Studies of the most suitable plant species for rhizoremediation showed that various grass varieties and leguminous plants such as alfalfa are suitable (Kuiper et al. 2001; Qiu et al. 1994; Shann and Boyle 1994). This probably is due to their ability to harbor large numbers of bacteria on their highly branched root systems. Success also depends on factors such as primary and secondary metabolism, and establishment, survival, and ecological interactions with other organisms. Plant roots were suggested as a substitute for the tilling of soil to incorporate additives and to improve aeration (Aprill and Sims 1990). The use of plants in combination with microbes has the advantage of causing an increase in microbial population numbers and metabolic activity in the rhizosphere. It also can establish an improvement of the physical and chemical properties of contaminated soil, and an increase in contact between the microbes associated with the roots and the contaminants in soil (Aprill and Sims 1990; Kingsley et al. 1994; Kuiper et al. 2001; Nichols et al. 1997; Schwab et al. 1995).

The rhizosphere: exudate nutrients and root colonization. The main reason for the improved degradation of pollutants in the rhizosphere is presumably the increase in the number and metabolic activity of microbes. The exudation of nutrients by plant roots creates a nutrient-rich environment in which microbial activity is stimulated. Plant root exudates contain sugars, organic acids, and amino acids as main components (Vancura and Hovadik 1965). In addition, the mucigel secreted by root cells, lost root cap cells, the starvation of root cells, or the decay of complete roots provides nutrients (Lugtenberg and de Weger 1992; Lynch and Whipps 1990; Rovira 1956). This stimulatory rhizosphere effect has been recognized for many years and was described for the first time by Hiltner (1904), who defined the rhizosphere as the zone of soil in which microbes are influenced by the root system. In turn, rhizosphere organisms also have a large impact on plants, because many microbes isolated from the rhizosphere are described to have root growth-stimulating or growth-inhibiting properties (Campbell and Greaves 1990). The composition of the microbial population in the rhizosphere depends on the composition of the root exudate as well as on the plant species (Shann and Boyle 1994), root type, plant age, soil type, and history of the soil (Anderson et al. 1993). It is known that the rhizosphere is dominated by gram-negative rods such as Pseudomonas spp. The presence and survival of beneficial rhizobacterial strains is, in contrast to the limited studies of rhizoremediation, described in more detail for processes such as biocontrol of soilborne plant diseases (Chin-A-Woeng et al. 1998; Weller 1988), biofertilization (e.g., by nitrogen fixing bacteria), and phytostimulation (Okon et al. 1998). The success of these beneficial processes is based on the rhizosphere competence of the microbes (Lugtenberg and Dekkers 1999; Weller and Thomashow 1994), which is reflected by the ability of the microbes to survive in the rhizosphere, compete for the exudate nutrients, sustain in sufficient numbers, and efficiently colonize the growing root system (Lugtenberg and Dekkers 1999). Coating of seed with bacteria is often used to apply beneficial microbes in a bioinoculant (Schippers et al. 1995; Weller and Thomashow 1994); this approach is most successful when the bioinoculant is well adapted to the rhizosphere. The ability to efficiently colonize plant roots varies strongly within

Table 1. Rhizoremediation of various environmental pollutants

\begin{tabular}{|c|c|c|c|}
\hline Plant & Pollutant $^{\mathrm{a}}$ & Microbes & Reference \\
\hline Rice (cv. Supriya) & Parathion & Not identified & Reddy and Sethunathan 1983 \\
\hline Mixture of grass, legume, herb and pine & TCE & Not identified & Walton and Anderson 1990 \\
\hline Prairie grasses & PAHs & Not identified & Aprill and Sims 1990 \\
\hline Prairie grasses & PAHs & Not identified & Qiu et al. 1994 \\
\hline Grasses and alfalfa & Pyrene, anthracene, phenanthrene & Not identified & Schwab et al. 1995 \\
\hline Sugar beet (cv. Rex) & PCBs & Pseudomonas fluorescens & Brazil et al. 1995 \\
\hline \multicolumn{4}{|l|}{ Undefined wild plants (Compositae) and } \\
\hline Senecus glaucus & Oil & Arthrobacter/Penicillium & Radwan et al. 1995 \\
\hline Barley (Hordeum vulgare) & $2,4-\mathrm{D}$ & Burkholderia cepacia & Jacobsen 1997 \\
\hline Alfalfa and alpine bluegrass & Hexadecane and PAHs & Not identified & Nichols et al. 1997 \\
\hline Wheat (Triticum aestivum) & $2,4-\mathrm{D}$ & Pseudomonas putida strains & Kingsley et al. 1994 \\
\hline Poplar (Populus deltoides nigra) & 1,4-dioxane & Actinomycetes & Schnoor et al. 1998 \\
\hline Wheat & TCE & P. fluorescens & Yee et al. 1998 \\
\hline Oat, lupin, rape, dill, pepper, radish, pine & Pyrene & Not identified & Liste and Alexander 2000 \\
\hline Reed (Phragmitis australies) & Fixed nitrogen & Nitrospira sp. and Nitrosomonas sp. & Abd El Haleem et al. 2000 \\
\hline Poplar root extract & 1,4-dioxane & Actinomycete Amycolata sp. CB1190 & Kelley et al. 2001 \\
\hline Corn (Zea mays) & 3-methylbenzoate & P. putida & Ronchel et al. 2001 \\
\hline Astragalus sinicus & $\mathrm{Cd}^{+}$ & Mesorhizobium huakuii & Sriprang et al. 2002 \\
\hline Fern (Azolla pinnata) & Diesel fuel & Not identified & Cohen et al. 2002 \\
\hline
\end{tabular}

${ }^{\mathrm{a}} \mathrm{TCE}=$ trichloroethylene, $\mathrm{PAHs}=$ polycyclic aromatic hydrocarbons, $\mathrm{PCBs}=$ polychlorinated biphenyls, and 2,4-D = 2,4-dichloro-phenoxyacetic acid. 
different Pseudomonas strains, indicating different rhizosphere competence abilities. In order to understand why these differences occur, the process of competitive root colonization was studied to unravel the molecular mechanisms behind it and was reviewed by Lugtenberg and associates (2001). This is of great importance because root colonization ability often is the limiting factor in successful biocontrol of soilborne plant diseases (Brand et al. 1990; Bull et al. 1991; Chin-A-Woeng et al. 2000; Weller and Thomashow 1994). $P$. fluorescens WCS365 (Geels and Schippers 1983) was selected for its excellent competitive root colonizing abilities, and was used as a model strain to study root colonization. The amino acid (Simons et al. 1997), sugar (Lugtenberg et al. 1999), and organic acid (de Weert et al. 2002) composition of tomato root exudate was analyzed and its influence on root colonization by WCS365 was reported. It was shown that amino acid concentrations in the tomato rhizosphere were not sufficient to complement auxotrophic mutants during competitive tomato root colonization (Simons et al. 1997). However, the important ability to efficiently use major exudate components during root colonization was underlined by the observation that a mutant impaired in the ability to use organic acids, which are five times more abundant in the exudate than sugars, was impaired in competitive root colonization, whereas a mutant in sugar metabolism was not hampered in its colonizing ability (Lugtenberg et al. 1999). Recently, it was shown that chemotaxis by WCS365 bacteria toward some organic acids and amino acids (but not to sugars) present in tomato root exudate plays an important role during root colonization (de Weert et al. 2002).

Another example of the importance of the efficient use of exudates was shown for P. putida PCL1444. The selection of this strain for survival and proliferation on grass roots coincided with very efficient use of the main organic acids and sug-

B
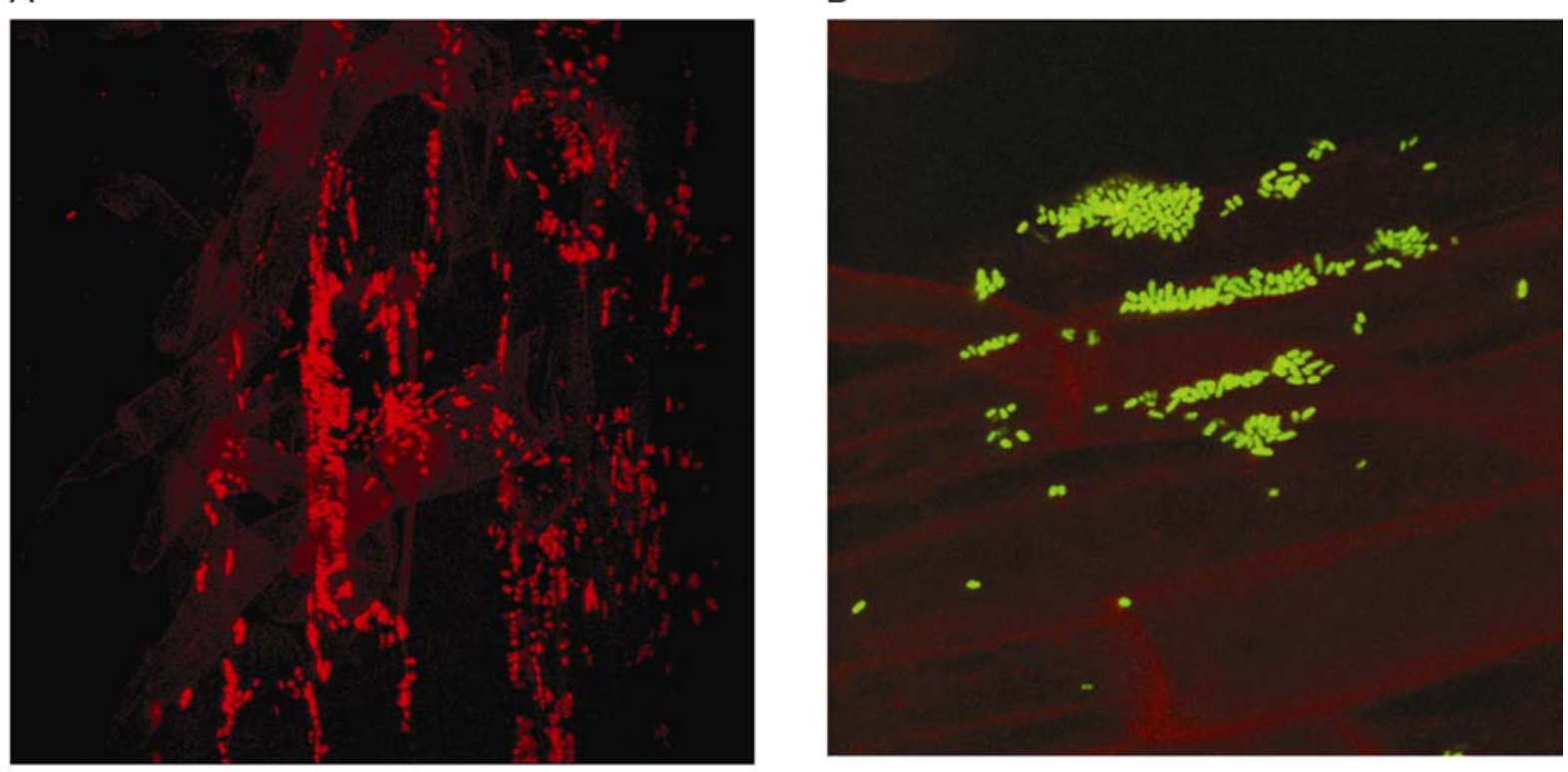

C

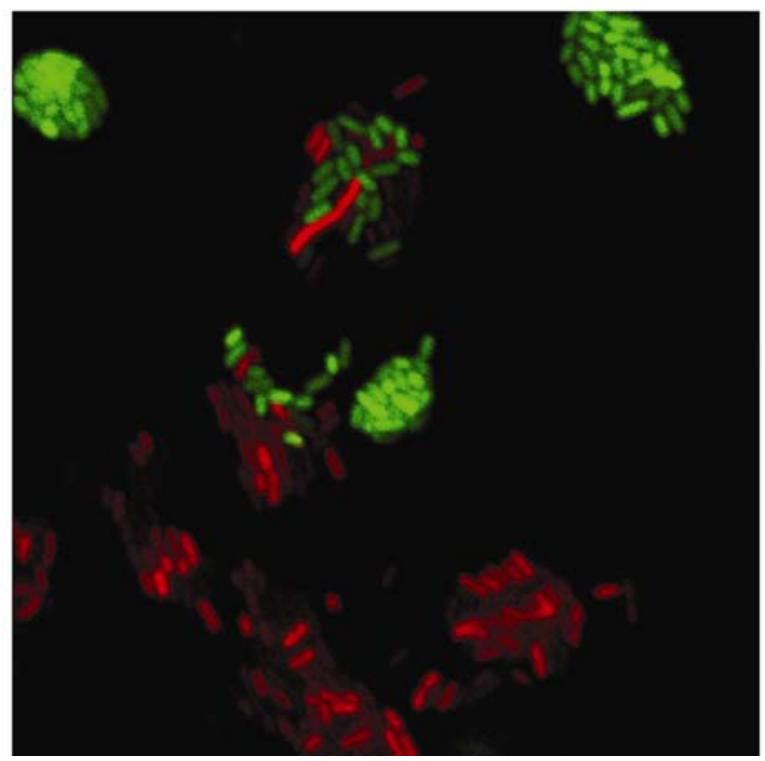

Fig. 3. Root colonization patterns of Pseudomonas putida PCL1444 and P. putida PCL1445. A, Cells of PCL1444, labeled with red fluorescent protein and $\mathbf{B}$, cells of PCL1445, labeled with enhanced green fluorescent protein in competition on grass roots, without naphthalene. C, Mixed microcolony with cells of PCL1444 and PCL1445 labeled with RFP and EGFP, respectively, in the presence of naphthalene. 
ars from the grass root exudate and with a high expression level of its catabolic genes for naphthalene degradation during the use of these substrates (Kuiper et al. 2002).

To study the patterns of microbial plant root colonization, different tools such as microscopy (Chin-A-Woeng et al. 1997; Rovira et al. 1974), microscopy combined with the use of marked strains (Bloemberg et al. 1997), or strains equipped with reporter genes (Beauchamp et al. 1993; Boivin et al. 1988; de Weger et al. 1991; Kloepper and Beauchamp 1992) can be used. During in vitro studies, it was shown that, upon inoculation of seed or seedlings, cells of Pseudomonas mainly appear as microcolonies along the junctions of epidermal plant cells where nutrients are exuded (Bloemberg et al. 2000; ChinA-Woeng et al. 1997). In addition, most bacterial cells were detected on the upper root parts and bacterial numbers decreased in the direction of the root tip.

Rhizoremediation potential for selected plant-microbe pairs. In many of the studies describing rhizoremediation (Table 1), the degrading rhizosphere communities emerge and develop during plant growth in the studied microcosm or field. Very few studies report the directed introduction of a microbial strain for xenobiotic degrading activities on plant seed, which subsequently is able to efficiently colonize the root and sustain on the root system (Kuiper et al. 2001; Ronchel and Ramos 2001; Sriprang et al. 2002).

Kuiper and associates (2001) hypothesized that, when a suitable rhizosphere strain is introduced together with a suitable plant (e.g., by coating bacteria on plant seed), these well-equipped bacteria might settle on the root together with the indigenous population, thereby enhancing the bioremediation process. In addition, such efficiently root-colonizing, pollutant-degrading bacteria then would profit from the growing root system because this would act as an injection system to spread the bacteria through the soil. Using a specially designed enrichment procedure, a plant-microbe combination was selected which caused the efficient degradation of naphthalene. Moreover, it even was able to protect grass seed against high naphthalene concentrations and to transport the bacteria through layers which they could not pass without roots (Kuiper et al. 2001). The study of Ronchel and Ramos (2001) reported the construction of a recombinant Pseudomonas strain equipped with a special biological containment system which makes this strain viable in the presence of a pollutant, and described its behavior in the rhizosphere compared to with parental strain.

Occurrence of pollutant-degrading microbial consortia in the rhizosphere. It is known that several bacterial populations degrade pollutants more efficiently than a single strain due to the presence of partners which use the various intermediates of the degradation pathway more efficiently (Pelz et al. 1999). A consortium of bacteria, each with different parts of the catabolic degradation route, involved in the degradation of a certain pollutant often is found to be more efficient than the introduction of one single strain with the complete pathway (Rahman et al. 2002). During rhizoremediation, the degradation of a pollutant, in many cases, is also the result of the action of a consortium (Table 1). The selection procedure described for P. putida PCL1444 (Kuiper et al. 2001) also resulted in the isolation of $P$. putida PCL1445. Surprisingly, PCL1445 does not grow as a pure culture in basic medium (BM) with naphthalene as the sole carbon source; instead, co-inoculation of the medium with mutants of PCL1444 impaired in different steps of the naphthalene degradation pathway, which therefore accumulate different naphthalene degradation intermediates (Fig. 2), showed that PCL1445 could grow in BM medium with naphthalene as the sole carbon source only if a mutant of PCL1444 is present, of which $\operatorname{dox} G$ (nahC homolog, involved in the conversion of 1,2 dihydroxy-naphthalene into cis-o-hydroxybenzalpyruvic acid) can be transcribed.

In order to study whether this joint metabolism also occurs in the grass rhizosphere, root colonization patterns of both strains were visualized in the presence and absence of naphthalene. Competitive grass root colonization experiments in which a 1:1 mixture of PCL1444 and PCL1445, labeled with different autofluorescent protein markers (Bloemberg et al. 2000) was applied on the seedlings, showed that cells of PCL1444 (Fig. 3A) and PCL1445 (Fig. 3B) appeared in microcolonies on the roots and were present mainly at the junctions between epidermal plant cells. This was described previously for other Pseudomonas strains on tomato roots by Chin-A-Woeng and associates (1997). Cells of strain PCL1445 were detected mostly on the upper root parts and on root hairs, whereas cells of strain PCL1444 were found mostly on the surface of the main root and also on lower root parts, but not on root hairs. The colonization of different niches by different strains was recognized earlier by Dekkers and associates (2000), who reported that, after application of two strains in competition, $P$. chlororaphis PCL1391 mainly colonized tomato root hairs, whereas $P$. fluorescens WCS365 mainly occupied the main root.

In the presence of naphthalene, colonization patterns of strain PCL1444 and PCL1445 show that cells of strain PCL1445 were detected at a high frequency near microcolonies of PCL1444 on the upper part of the root system. In addition, many mixed microcolonies of the two strains were observed (Fig. 3C). The close proximity of the strains and the formation of mixed microcolonies were only rarely or not, respectively, observed in the absence of naphthalene. These results show that communities are formed on roots in the presence of naphthalene, presumably because PCL1444 secretes naphthalene intermediates that are used by PCL1445 when the strains are near each other on the root.

\section{CONCLUSIONS}

Bioremediation is recognized as a suitable tool to restore contaminated sites. The combination of bioaugmentation and phytoremediation, resulting in rhizoremediation, could solve some of the problems encountered during the application of both individual techniques. Many studies (Table 1) already show that rhizoremediation can contribute to the restoration of polluted sites. However, not many reports are present about the actual selection of a suitable rhizoremediation system, consisting of a plant inoculated with a bacterium or a consortium with degradation capacity. Although the studies described above about selection of suitable combinations represent data for only one pollutant and for one plant-bacterium combination, it is clear that similar microbe-plant combinations can be selected for other pollutants. Therefore, further studies of the selection of suitable rhizosphere bacteria or communities, able to sustain and proliferate on the root system of a plant which is suitable for rhizoremediation or phytoremediation, can yield useful novel (engineered) systems. These systems then can be an interesting tool to further improve and develop bioremediation into a widely accepted technique.

\section{LITERATURE CITED}

Abd El Haleem, D., von Wintzingerode, F., Moter, A., Moawad, H., and Gobel, U. B. 2000. Phylogenetic analysis of rhizosphere-associated beta-subclass proteobacterial ammonia oxidizers in a municipal wastewater treatment plant based on rhizoremediation technology. Lett. Appl. Microbiol. 31:34-38.

Allen, C. C. R., Boyd, D. R., Hempenstall, F., Larkin, M. J., and Sharma, N. D. 1999. Contrasting effects of a nonionic surfactant on the bio- 
transformation of polycyclic aromatic hydrocarbons to cis-dihydrodiols by soil bacteria. Appl. Environ. Microbiol. 65:1335-1339.

Anderson, T. A., Guthrie, E. A., and Walton, B. T. 1993. Bioremediation in the rhizosphere. Environ. Sci. Technol. 27:2630-2636.

Aprill, W., and Sims, R. C. 1990. Evaluation of the use of prairie grasses for stimulating polycyclic aromatic hydrocarbon treatment in soil. Chemosphere 20:253-265.

Barton, A. 2000. Modeling chloroethene behavior in groundwater in support of natural attenuation. Pages 89-96 in: Natural Attenuation Considerations and Case Studies: Remediation of Chlorinated and Recalcitrant Compounds. G. B. Wickramanayake, A. R. Gavaskar, and M. E. Kelley, eds. Batelle Press, Columbus, OH, U.S.A.

Beauchamp, C. J., Kloepper, J. W., and Lemke, P. A. 1993. Luminometric analyses of plant root colonization by bioluminescent pseudomonads. Can. J. Microbiol. 39:434-441.

Best, E. P., Zappi, M. E., Fredrickson, H. L., Sprecher, S. L., Larson, S. L., and Ochman, M. 1997. Screening of aquatic and wetland plant species for phytoremediation of explosives-contaminated groundwater from the Iowa Army Ammunition Plant. Ann. N. Y. Acad. Sci. 829:194.

Bizily, S. P., Rugh, C. L., and Meagher, R. B. 2000. Phytodetoxification of hazardous organomercurials by genetically engineered plants. Nature Biotechnol. 18:213-217.

Blackburn, J. W., and Hafker, W. R. 1993. The impact of biochemistry, bioavailability and bioactivity on the selection of bioremediation techniques. Tibtech 11:328-333.

Bloemberg, G. V., O'Toole, G. A., Lugtenberg, B. J. J., and Kolter, R. 1997. Green fluorescent protein as a marker for Pseudomonas spp. Appl. Environ. Microbiol. 63:4543-4551.

Bloemberg, G. V., Wijfjes, A. H. M., Lamers, G. E. M., Stuurman, N., and Lugtenberg, B. J. J. 2000. Simultaneous imaging of Pseudomonas fluorescens WCS365 populations expressing three different autofluorescent proteins in the rhizosphere: new perspectives for studying microbial communities. Mol. Plant-Microbe Interact. 13:1170-1176.

Boivin, R., Chalifour, F. P., and Dion, P. 1988. Construction of a Tn5 derivative encoding bioluminescence and its introduction in Pseudomonas, Agrobacterium and Rhizobium. Mol. Gen. Genet. 213:50-55.

Bouwer, E. J., and Zehnder, A. J. B. 1993. Bioremediation of organic compounds- putting microbial metabolism to work. Tibtech 11:360267.

Brand, J., Lugtenberg, B. J. J., Glandorf, D. C. M., Bakker, P. A. H. M., Schippers, B., and de Weger, L. A. 1990. Isolation and characterization of a superior potato root- colonizing Pseudomonas strain. Pages 350354 in: Plant Growth Promoting Rhizobacteria-Progress and Prospects. C. Keel, B. Koller, and G. Défago, eds. IOBC/WPRS Bull. XIV8. Interlaken, Switzerland.

Brazil, G. M., Kenefick, L., Callanan, M., Haro, A., de Lorenzo, V., Dowling, D. N., and O'Gara, F. 1995. Construction of a rhizosphere Pseudomonad with potential to degrade polychlorinated biphenyls and detection of $b p h$ gene expression in the rhizosphere. Appl. Environ. Microbiol. 61:1946-1952.

Brodkorb, T. S., and Legge, R. L. 1992. Enhanced biodegradation of phenanthrene in oil tar-contaminated soils supplemented with Phanerochaete chrysosporium. Appl. Environ. Microbiol. 58:3117-3121.

Bull, C. T., Weller, D. M., and Thomashow, L. S. 1991. Relationship between root colonization and suppression of Gaeumannomyces graminis var. triciti by Pseudomonas fluorescens strain 2-79. Phytopathology 81:954-959.

Campbell, R., and Greaves, M. P. 1990. Anatomy and community structure of the rhizosphere. Pages 11-34 in: The Rhizosphere. J. M. Lynch, ed. Wiley \& Sons, Chichester, UK.

Caplan, J. A. 1993. The worldwide bioremediation industry: prospects for profit. Tibtech 11:320-323.

Cerniglia, C. E. 1993. Biodegradation of polycyclic aromatic hydrocarbons. Curr. Opin. Biotechnol. 4:331-338.

Cerniglia, C. E. 1997. Fungal metabolism of polycyclic aromatic hydrocarbons; past, present and future applications in bioremediation. J. Ind. Microbiol. Biotechnol. 19:324-333.

Cerniglia, C. E., and Heitkamp, M. A. 1987. Microbial degradation of polycyclic aromatic hydrocarbons $(\mathrm{PAH})$ in the aquatic environment. Pages 41-68 in: Metabolism of Polycyclic Aromatic Hydrocarbons in the Aquatic Environment. U. Varanasi, ed. CRC Press, Inc., Boca Raton, FL, U.S.A.

Chakrabarty, A. M. 1996. Microbial degradation of toxic chemicals: Evolutionary insights and practical considerations. ASM News 62:130-137.

Chin-A-Woeng, T. F. C., Bloemberg, G. V., Mulders, I. H. M., Dekkers, L. C., and Lugtenberg, B. J. J. 2000. Root colonization is essential for biocontrol of tomato foot and root rot by the phenazine-1-carboxamide-producing bacterium Pseudomonas chlororaphis PCL1391. Mol. Plant-Microbe Interact. 13:1340-1345.
Chin-A-Woeng, T. F. C., Bloemberg, G. V., van der Bij, A. J., van der Drift, K. M. G. M., Schripsema, J., Kroon, B., Scheffer, R. J., Keel, C., Bakker, P. A. H. M., Tichy, H.-V., de Bruijn, F. J., Thomas-Oates, J. E., and Lugtenberg, B. J. J. 1998. Biocontrol by phenazine-1-carboxamide-producing Pseudomonas chlororaphis PCL1391 of tomato root caused by Fusarium oxysporum f. sp. radicis-lycopersici. Mol. PlantMicrobe Interact. 11:1069-1077.

Chin-A-Woeng, T. F. C., De Priester, W., van der Bij, A. J., and Lugtenberg, B. J. J. 1997. Description of the colonization of a gnotobiotic tomato rhizosphere by Pseudomonas fluorescens biocontrol strain WCS365, using scanning electron microscopy. Mol. Plant-Microbe Interact. 10:79-86

Clemens, S., Palmgren, M. G., and Kramer, U. 2002. A long way ahead: understanding and engineering plant metal accumulation. Trends Plant Sci. 7:309-315.

Cobbett, C., and Goldsbrough, P. 2002. Phytochelatins and metallothioneins: roles in heavy metal detoxification and homeostasis Annu. Rev. Plant. Biol. 53:159-182.

Cohen, M. F., Williams, J., and Yamasaki, H. 2002. Biodegradation of diesel fuel by an Azolla-derived bacterial consortium. J. Environ. Sci. Health Part A Toxic-Hazard Subst. Environ. Eng. 37:15931606

Dagher, F., Deziel, E., Lirette, P., Paquette, G., Bisaillon, J., and Villemur, R. 1997. Comparative study of five polycyclic aromatic hydrocarbon degrading bacterial strains isolated from contaminated soils. Can. J. Microbiol. 43:368-377.

Davies, J. I., and Evans, W. C. 1964. Oxidative metabolism of naphthalene by soil Pseudomonads. Biochem. J. 91:251-261.

Dean-Ross, D. 1987. Biodegradation of toxic wastes in soil. ASM News 53:490-492.

Dekkers, L. C., Mulders, I. H. M., Phoelich, C. C., Chin-A-Woeng, T. F. C., Wijfjes, A. H. M., and Lugtenberg, B. J. J. 2000. The sss colonization gene of the tomato-Fusarium oxysporum f. radicis-lycopersici biocontrol strain Pseudomonas fluorescens WCS365 can improve root colonization of other wild-type Pseudomonas spp. bacteria. Mol. Plant-Microbe Interact. 13:1177-1183.

Desai, J. D., and Banat, I. M. 1997. Microbial production of surfactants and their commercial potential. Microbiol. Mol. Biol. Rev. 61:47-64.

de Weert, S., Vermeiren, H., Mulders, I. H. M., Kuiper, I., Hendrickx, N., Bloemberg, G. V., Vanderleyden, J., De Mot, R., and Lugtenberg, B. J. J. 2002. Flagella-driven chemotaxis towards exudate components is an important trait for tomato root colonization by Pseudomonas fluorescens. Mol. Plant-Microbe Interact. 15:11731180

de Weger, L. A., Dunbar, P., Mahafee, W., Lugtenberg, B. J. J., and Sayler, G. S. 1991. Use of bioluminescence markers for detection of Pseudomonas bacteria in the rhizosphere. Appl. Environ. Microbiol. 57:3641-3644.

Dixon, B. 1996. Bioremediation is here to stay. ASM News 62:527-528.

Doty, S. L., Shang, T. Q., Wilson, A. M., Tangen, J., Westergreen, A. D. Newman, L. A., Strand, S. E., and Gordon, M. P. 2000. Enhanced metabolism of halogenated hydrocarbons in transgenic plants containing mammalian cytochrome P450 2e1. Proc. Natl. Acad. Sci. U.S.A. 97:6287-6291

Dua, M., Sethunathan, N., and Johri, A. K. 2002. Biotechnology and bioremediation: successes and limitations. Appl. Microbiol. Biotechnol. 59:143-152.

Erickson, L. E. 1997. An overview of research on the beneficial effects of vegetation in contaminated soil. Ann. N. Y. Acad. Sci. 829:30-35

Ford, C. Z., Sayler, G. S., and Burlage, R. S. 1999. Containment of a genetically engineered microorganism during a field bioremediation application. Appl. Microbiol. Biotechnol. 51:397-400.

Fuma, S., Fujishima, Y., Corbell, N., Souza, C., Nakano, M. M., Zuber, P., and Yamane, K. 1993. Nucleotide sequence of 5' portion of srfA that contains the region required for competence establishment in Bacillus subtilus. Nucleic Acids Res. 21:93-97.

Geels, F. P., and Schippers, B. 1983. Selection of antagonistic fluorescent Pseudomonas spp. and their root colonization and persistence following treatment of seed potatoes. Phytopathol. Z. 108:193-206.

Gleba, D., Borisjuk, N. V., Borisjuk, L. G., Kneer, R., Poulev, A., Skarzhinskaya, M., Dushenkov, S., Logendra, S., Gleba, Y., and Raskin, I. 1999. Use of plants roots for phytoremediation and molecular farming. Proc. Natl. Acad. Sci. U.S.A. 96:5973-5977.

Goldstein, R. M., Mallory, L. M., and Alexander, M. 1985. Reasons for possible failure of inoculation to enhance biodegradation. Appl. Environ. Microbiol. 50:977-983.

Gordon, M., Choe, N., Duffy, J., Ekuan, G., Heilman, P., Muiznieks, I., Ruszaj, M., Shurtleff, B. B., Strand, S., Wilmoth, J., and Newman, L. A. 1998. Phytoremediation of trichloroethylene with hybrid poplars. Environ. Health Perspect. 106:1001-1004. 
Grimm, A. C., and Harwood, C. S. 1997. Chemotaxis of Pseudomonas spp. to the polyaromatic hydrocarbon naphthalene. Appl. Environ. Microbiol. 63:4111-4115.

Grosser, R. J., Warshawsky, D., and Vestal, J. R. 1991. Indigenous and enhanced mineralization of pyrene, benzo(a)pyrene, and carbazole in soils. Appl. Environ. Microbiol. 57:3462-3469.

Grossl, P. R. 2000. Natural attenuation mechanisms of inorganic pollutants: sorption/desorption kinetics on soil mineral surfaces. Pages 201207 in: Natural Attenuation Considerations and Case Studies: Remediation of Chlorinated and Recalcitrant Compounds. Battelle Press, Columbus, OH, U.S.A.

Hamer, G. 1993. Bioremediation: a response to gross environmental abuse. Tibtech 11:317-319.

Head, I. M. 1998. Bioremediation: towards a credible technology. Microbiology 144:599-608.

Heidelberg, J. F., Paulsen, I. T., Nelson, K. E., Gaidos, E. J., Nelson, W. C., Read, T. D., and Eisen, J. A. 2002. Genome sequence of the dissimilatory metal ion-reducing bacterium Shewanella oneidensis. Nature Biotechnol. 1:1-6.

Heitkamp, M. A., and Cerniglia, C. E. 1989. Polycyclic aromatic hydrocarbon degrading by a mycobacterium sp. in microcosms containing sediment and water from a pristine ecosystem. Appl. Environ. Microbiol. 55:1968-1973.

Heitzer, A., and Sayler, G. S. 1993. Monitoring the efficacy of bioremediation. Tibtech 11:334-343.

Hiltner, L. 1904. Uber neue Erfahrungen und Probleme auf dem Gebiet der Bodenbakteriolgie und unter besonderes Berucksichtigung der Grundugungen und Brauche. Arb. Dtsch. Landwirtsch. Ges. Berlin 98:59-78.

Hoagland, R. E., Zablotowicz, R. M., and Locke, M. A. 1994. Propanil metabolism by rhizosphere microflora. Pages 160-183 in: Bioremediation through Rhizosphere Technology. T. A. Anderson and J. R. Coats, eds. American Chemical Society, Washington, D.C.

Iimura, Y., Ikeda, S., Sonoki, T., Hayakawa, T., Kajita, S., Kimbara, K. Tatsumi, K., and Katayama. Y. 2002. Expression of a gene for Mn-peroxidase from Coriolus versicolor in a transgenic tobacco generates potential tools for phytoremediation. Appl. Microbiol. Biotechnol. 59:246-251.

Jacobsen, C. S. 1997. Plant protection and rhizosphere colonization of barley by seed inoculated herbicide degrading Burkholderia (Pseudomonas) cepacia DBO1(pRO101) in 2,4-D contaminated soil. Plant Soil 189:139-144.

Johnson, K., and Jacobsen, C. S. 1996. Phenotypic and genotypic characterization of phenanthrene-degrading fluorescent Pseudomonas biovars. Appl. Environ. Microbiol. 62:3818-3825.

Kanaly, R. A., and Harayama, S. 2000. Biodegradation of high-molecular-weight polycyclic aromatic hydrocarbons by bacteria. J. Bacteriol. 182:2059-2067.

Kas, J., Burkard, J., Demnerova, K., Kostal, J., Macek, T., Mackova, M., and Pazlarova, J. 1997. Perspectives in biodegradation of polychlorinated biphenyls by plant cells. Pure Appl. Chem. 69:2369.

Kastner, M., Breuer-Jammali, M., and Mahro, B. 1998. Impact of Inoculation protocols, salinity, and $\mathrm{PH}$ on the degradation of polycyclic aromatic hydrocarbons (PAHs) and survival of PAH-degrading bacteria introduced into soil. Appl. Environ. Microbiol. 64:359-362.

Kastner, M., and Mahro, B. 1996. Microbial degradation of polycyclic aromatic hydrocarbons in soils affected by the organic matrix of compost. Appl. Microbiol. Biotechnol. 44:668-675.

Kelley, S. L., Aitchison, E. W., Deshpande, M., Schnoor, J. L., and Alvarez, P. J. 2001. Biodegradation of 1,4-dioxane in planted and unplanted soil: effect of bioaugmentation with Amycolata sp. CB1190. Water Res. 35:3791-3800.

Khan, A. G., Kuek, C., Chaudhry, T. M., Khoo, C. S., and Hayes, W. J. 2000. Role of plants, mycorrhizae and phytochelators in heavy metal contaminated land remediation. Chemosphere 41:197-207.

King, J. M. H., DiGrazia, P. M., Applegate, B., Larimer, F., and Sayler, G. S. 1990. Rapid, sensitive bioluminescent reporter technology for naphthalene exposure and biodegradation. Science 249:778-781.

Kingsley, M. T., Fredrickson, J. K., Metting, F. B., and Seidler, R. J. 1994. Environmental restoration using plant-microbe bioaugmentation. Pages 287-292 in: Bioremediation of Chlorinated and Polyaromatic Hydrocarbon Compounds. R. E. Hinchee, A. Leeson, L. Semprini, and S. K. Ong, eds. Lewis Publishers, Boca Raton, FL, U.S.A.

Kloepper, J. W., and Beauchamp, C. J. 1992. A review of issues related to measuring colonization of plant roots by bacteria. Can. J. Microbiol. 38:1219-1232.

Kuiper, I., Bloemberg, G. V., and Lugtenberg, B. J. J. 2001. Selection of a plant-bacterium pair as a novel tool for rhizostimulation of polycyclic aromatic hydrocarbon-degrading bacteria. Mol. Plant-Microbe Interact. 14:1197-1205.
Kuiper, I., Kravchenko, L., Bloemberg, G. V., and Lugtenberg, B. J. J. 2002. Pseudomonas putida strain PCL1444, selected for efficient root colonization and naphthalene degradation, effectively utilizes root exudate components. Mol. Plant-Microbe Interact. 15:734-741.

Lang, S., and Wullbrandt, D. 1999. Rhamnose lipids-biosynthesis, microbial production and application potential. Appl. Microbiol.Biotechnol. 51:22-32.

Leahy, J. G., and Colwell, R. R. 1990. Microbial degradation of hydrocarbons in the environment. Microbiol. Rev. 54:305-315.

Liste, H.-H., and Alexander, M. 2000. Plant-promoted pyrene degradation in soil. Chemosphere 40:7-10.

Liu, S., and Suflita, J. M. 1993. Ecology and evolution of microbial populations for bioremediation. Tibtech 11:344-352.

Long, G. M. 1993. Clean up hydrocarbon contamination effectively. Chem. Eng. Progress. 5:58-67.

Lugtenberg, B. J. J., and Dekkers, L. C. 1999. What makes Pseudomonas bacteria rhizosphere competent. Environ. Microbiol. 1:9-13.

Lugtenberg, B. J. J., Dekkers, L. C., and Bloemberg, G. V. 2001. Molecular determinants of rhizosphere colonization by Pseudomonas. Annu. Rev. Phytopathol. 39:461-490.

Lugtenberg, B. J. J., and de Weger, L. A. 1992. Plant root colonization by Pseudomonas spp. Pages 13-19 in: Pseudomonas: Molecular Biology and Biotechnology. E. Galli, S. Silver, and B. Witholt, eds. Am. Soc. Microbiol. Washington, D.C.

Lugtenberg, B. J. J., Kravchenko, L. V., and Simons, M. 1999. Tomato seed and root exudate sugars: composition, utilization by Pseudomonas biocontrol strains and role in rhizosphere colonization. Environ. Microbiol. 1:439-446.

Lynch, J. M. and J. M. Whipps. 1990. Substrate flow in the rhizosphere. Plant Soil 129:1-10.

Mahro, B., Schaefer, G., and Kästner, M. 1994. Pathways of microbial degradation of polycyclic aromatic hydrocarbons in soil. Pages 203 217 in: Bioremediation of Chlorinated and Polycyclic Aromatic Hydrocarbon Compounds. R. E. Hinchee, A. Leeson, L. Semprini, and S. K. Ong, eds. Lewis Publishers, Boca Raton, FL, U.S.A..

Manilal, V. B., and Alexander, M. 1991. Factors affecting the microbial degradation of phenanthrene in soil. Appl. Microbiol. Biotechnol. 35:401-405.

Meagher, R. B. 2000. Phytoremediation of toxic elemental organic pollutants. Curr. Opin. Plant Biol. 3:162.

Megharaj, M., Jovcic, A., Boul, H. L., and Thiele, J. H. 1997. Recalcitrance of 1,1-dichloro-2,2-bis(p-chlorophenyl)ethylene (DDE) to cometabolic degradation by pure cultures of aerobic and anaerobic bacteria. Arch. Environ. Contam. Toxicol. 33:141-146.

Morgan, P., and Watkinson, R. J. 1989. Hydrocarbon degradation in soil and methods for soil biotreatment. Crit. Rev. Biotechnol. 8:305-333.

Namkoong, W., Hwang, E. Y., Park, J. S., and Choi, J. Y. 2002. Bioremediation of diesel-contaminated soil with composting. Environ. Pollut. 119:23-31.

Neu, T. R. 1996. Significance of bacterial surface-active compounds in interaction of bacteria with interfaces. Microbiol. Rev. 60:151-166.

Nichols, T. D., Wolf, D. C., Rogers, H. B., Beyrouty, C. A., and Reynolds, C. M. 1997. Rhizosphere microbial populations in contaminated soils. Water Air Soil Pollut. 95:165-178.

Noordman, W., and Janssen, D. B. 2002. Rhamnolipid stimulates uptake of hydrophobic compounds by Pseudomonas aeruginosa. Appl. Environ. Microbiol. 68:4502-4508.

Okon, Y., Bloemberg, G. V., and Lugtenberg, B. J. J. 1998. Biotechnology of biofertilization and phytostimulation. In: Agricultural Biotechnology. A. Altman, ed. Dekker, New York.

Pelz, O., Tesar, M., Wittich, R.-M., Moore, E. R. B., Timmis, K. N., and Abraham, W.-R. 1999. Towards elucidation of microbial community metabolic pathways; unraveling the network of carbon sharing in a pollutant-degrading bacterial consortium by immunocapture and isotopic ratio mass spectrometry. Environ. Microbiol. 1:167-174.

Pieper, D. H., and Reineke, W. 2000. Engineering bacteria for bioremediation. Curr. Opin. Biotechnol. 11:262-270.

Pritchard, P. H., Mueller, J. G., Rogers, J. C., Kremer, F. V., and Glaser, J. A. 1992. Oil spill bioremediation: experiences, lessons and results from the Exxon Valdez oil spill in Alaska. Biodegradation 3:315-335.

Providenti, M. A., Flemming, C. A., Lee, H., and Trevors, J. T. 1995. Effect of addition of rhamnolipid biosurfactant or rhamnolipid-producing Pseudomonas aeruginosa on phenanthrene mineralization in soil slurries. FEMS (Fed. Eur. Microbiol. Soc.) Microbiol. Ecol. 17:15-26.

Qiu, X., Shah, S. I., Kendall, E. W., Sorensen, D. L., Sims, R. C., and Engelke, M. C. 1994. Grass-enhanced bioremediation for clay soils contaminated with polynuclear aromatic hydrocarbons. Pages 142157 in: Bioremediation Through Rhizosphere Technology. T. A Anderson and J. R. Coats, eds. American Chemical Society, Washington, D.C. 
Radwan, S., Sorkhoh, N., and El-Nemr, I. 1995. Oil biodegradation around roots. Nature 376:302.

Rahman, K. S., Rahman, T., Lakshmanaperumalsamy, P., and Banat, I. M. 2002. Occurrence of crude oil degrading bacteria in gasoline and diesel station soils. J. Basic Microbiol. 42:284-291.

Ramadan, M. A., Tayeb, O. M., and Alexander, M. 1990. Inoculation size as a factor limiting success of inoculation for biodegradation. Appl. Environ. Microbiol. 56:1392-1396.

Reddy, B. R., and Sethunathan, N. 1983. Mineralization of parathion in the rice rhizosphere. Appl. Environ. Microbiol. 45:826-829.

Ronchel, M. C., and Ramos, J. L. 2001. Dual system to reinforce biological containment of recombinant bacteria designed for rhizoremediation. Appl. Environ. Microbiol. 67:2649-2656.

Rosenberg, E. 1993. Exploiting microbial growth on hydrocarbons-new markets. Tibtech 11:419-424.

Rovira, A. D. 1956. Plant root excretions in relation to the rhizosphere effect. Plant Soil 7:209-217.

Rovira, A. D., Newman, E. I., Bowen, H. J., and Campbell, R. 1974 Quantitative assessment of the rhizoplane microflora by direct microscopy. Soil Biol. Biochem. 6:211-216.

Sanseverino, J., Applegate, B. M., King, J. M. H., and Sayler, G. S. 1993. Plasmid mediated mineralization of naphthalene, phenanthrene, and antrhacene. Appl. Environ. Microbiol. 59:1931-1937.

Sayler, G. S., and Ripp, S. 2000. Field applications of genetically engineered microorganisms for bioremediation processed. Curr. Opin. Biotech. 11:286-289.

Schippers, B., Scheffer, R. J., Lugtenberg, B. J. J., and Weisbeek, P. J. 1995. Biocoating of seeds with plant growth-promoting rhizobacteria to Improve plant establishment. Outlook Agric. 25:179-185

Schnoor, J. L., Aitchison, E. W., Kelley, S. L., and Alvarez, P. J. J. 1998. Phytoremediation and bioaugmentation of 1,4-dioxane. Pages 87-91. Abstr. Adv. Biol. Syst. Rem. Conf. March 1998.

Schwab, A. P., and Banks, M. K. 1994. Biologically mediated dissipation of polyaromatic hydrocarbons in the root zone. Pages 132 141 in: Bioremediation Through Rhizosphere Technology. T. A. Anderson and J. R. Coats, eds. American Chemical Society, Washington, DC

Schwab, A. P., Banks, M. K., and Arunachalam, M. 1995. Biodegradation of polycyclic aromatic hydrocarbons in rhizosphere soil. Pages 23-29 in: Bioremediation of Recalcitrant Organics. R. E. Hinchee, D. B. Anderson, and R. E. Hoeppel, eds. Battelle Memorial Institute, Columbus, OH, U.S.A.

Shann, J. R., and Boyle, J. J. 1994. Influence of plant species on in situ rhizosphere degradation. Pages 70-81 in: Bioremediation Through Rhizosphere Technology. T. A. Anderson and J. R. Coats, eds. American Chemical Society, Washington, DC.

Shimizu, M., Kimura, M., Koyama, T., Suzuki, F., Ogawa, N., Miyashita, K., Sakka, K., and Ohmiya, K. 2002. Molecular breeding of transgenic rice plants expressing a bacterial chlorocatechol dioxygenase gene. Appl. Environ. Microbiol. 68:4061-4066.

Shreve, G. S., Inguva, S., and Gunnam, S. 1995. Rhamnolipid biosurfactant enhancement of hexadecane biodegradation by Pseudomonas aeruginosa. Mol. Marine Biol. Biotechnol. 4:331-337.

Shuttleworth, K. L., and Cerniglia, C. E. 1996. Bacterial degradation of low concentration of phenanthrene and inhibition by naphthalene. Microb. Ecol. 31:305-317.

Sim, L., Ward, O. P., and Li, Z.-Y. 1997. Production and characterization of a biosurfactant isolated from Pseudomonas aeruginosa UW-1. J. Ind. Microbiol. Biotechnol. 19:232-238.

Simons, M., Permentier, H. P., de Weger, L. A., Wijffelman, C. A., and Lugtenberg, B. J. J. 1997. Amino acid synthesis is necessary for tomato root colonization by Pseudomonas fluorescens strain WCS365. Mol. Plant-Microbe Interact. 10:102-106.
Smets, B. F., Siciliano, S. D., and Verstraete, W. 2002. Natural attenuation: extant microbial activity forever and ever? Environ. Microbiol. 4:315-317.

Spadaro, J. T. 2000. Natural attenuation assessment of a highly impacted trichloroethene site. Pages 129-136 in: Natural Attenuation Considerations and Case Studies: Remediation of Chlorinated and Recalcitrant Compounds. G. B. Wickramanayake, A. R. Gavaskar, and M. E. Kelley, eds. Battelle Press, Columbus, OH, U.S.A.

Sriprang, R., Hayashi, M., Yamashita, M., Ono, H., Saeki, K., and Murooka, Y. 2002. A novel bioremediation system for heavy metals using the symbiosis between leguminous plant and genetically engineered rhizobia. J. Biotechnol. 99:279-293.

Stuart-Keil, K. G., Hohnstock, A. M., Drees, K. P., Herrick, J. B., and Madsen, E. L. 1998. Plasmids responsible for horizontal transfer of naphthalene catabolism genes between bacteria at a coal tar-contaminated site are homologous to pDTG1 from Pseudomonas putida NCIB 9816-4. Appl. Environ. Microbiol. 64:3633-3640.

Timmis, K. N., and Pieper, D. H. 1999. Bacteria designed for bioremediation. Tibtech 17:201-204.

van Agteren, M. H., Keuning, S., and Janssen, D. B. 1998. Polyaromatic hydrocarbons (PAHs). Pages 289-349 in: Handbook on Biodegradation and Biological Treatment of Hazardous Organic Compounds. Kluwer Academic Publishers, Dordrecht, The Netherlands.

Vancura, V., and Hovadik, A. 1965. Root exudates of plants II. Composition of root exudates of some vegetables. Plant Soil 22:21-32.

Walton, B. T., and Anderson, T. A. 1990. Microbial degradation of trichloroethylene in the rhizosphere: Potential application to biological remediation of waste sites. Appl. Environ. Microbiol. 56:1012-1016.

Wang, X., Yu, X., and Bartha, R. 1990. Effect of bioremediation on polycyclic aromatic hydrocarbon residues in soil. Environ. Sci. Technol. 24:1086-1089.

Weller, D. M. 1988. Biological control of soilborne plant pathogens in the rhizosphere with bacteria. Annu. Rev. Phytopathol. 26:379-407.

Weller, D. M., and Thomashow, L. S. 1994. Current challenges in introducing beneficial microorganisms into the rhizosphere. Pages 1-17 in: Molecular Ecology of Rhizosphere Organisms. F. O'Gara, D. N Dowling, and B. Boesten, eds. VCH Verlagsgesellschaft $\mathrm{mbH}$., Weinheim, Germany.

Widada, J., Nojiri, H., and Omori, T. 2002. Recent developments in molecular techniques for identification and monitoring of xenobioticdegrading bacteria and their catabolic genes in bioremediation. Appl. Microbiol. Biotechnol. 60:45-59.

Yakimov, M. M., Timmis, K. N., Wray, V., and Fredrickson, H. L. 1995. Characterization of a new lipopeptide surfactant produced by thermotolerant and halotolerant subsurface Bacillus licheniformis BAS50. Appl. Environ. Microbiol. 61:1706-1713.

Yee, D. C., Maynard, J. A., and Wood, T. K. 1998. Rhizoremediation of trichloroethylene by a recombinant, root-colonizing Pseudomonas fluorescens strain expressing toluene ortho- monooxygenase constitutively. Appl. Environ. Microbiol. 64:112-118.

Yen, K. M., and Serdar, C. M. 1988. Genetics of naphthalene catabolism in pseudomonads. Crit. Rev. Biotechnol. 15:247-268.

Zablotowicz, R. M., Hoagland, R. E., and Locke, M. A. 1994. Glutathione S-transferase activity in rhizosphere bacteria and the potentia for herbicide detoxification. Pages 184-198 in: Bioremediation Through Rhizosphere Technology. T. A. Anderson and J. R. Coats, eds. American Chemical Society, Washington, DC.

\section{AUTHOR-RECOMMENDED INTERNET RESOURCE}

United States Environmental Protection Agency website: www.epa.gov 